\title{
Estimation of the Efficiency of Working Time Usage as a Factor of Sustainable Increase of Labor Productivity
}

\author{
I.V. Bogatyreva ${ }^{1, *}$, L.A. Ilyukhina ${ }^{1}, M . V$. Simonova $^{1}$ and N.V. Kozhukhova ${ }^{1}$ \\ *Corresponding author: scorpiony70@mail.ru \\ ${ }^{1}$ Samara State University of Economics, Samara, Russia
}

\begin{abstract}
The article views rationalization of working time as the most important factor of the labor productivity of personnel. Rationalization of working time is aimed at reducing losses and unproductive costs caused by deficiencies in the system of production support, its management and organization. Improving the use of working time, it is possible to increase productivity of labor very quickly without attracting additional funding. This stipulates the relevance of the study of the issues of efficient use of working time and reducing its losses and unproductive costs. The objectives of the study, the results of which are reflected in this article, were the analysis of the problems connected with inefficient use of working time at Russian enterprises and the search for ways to solve them as well as the development of an algorithm for calculating and evaluating working time efficiency. The authors of the article justified the procedure for evaluating the efficiency of working time, analyzed the structure of work at the preparatory and final stage and the time of workplace maintenance, the composition of losses and unproductive use of working time. Calculating of the possible increase of labor productivity due to better use of working time on the example of one of Samara enterprises is given. A flowchart of the analysis of working time efficiency and the assessment of reserves for labor productivity increase are presented; the main directions of improving the use of working time at enterprises are given, taking into account the reasons of its losses and unproductive costs.
\end{abstract}

Keywords: time balance, inefficient costs, time loss, reserves for labor productivity increase, efficiency of time use.

\section{Introduction}

The central problem of the Russian economy is the unsatisfactory state of labor productivity and a significant lag in the level of labor productivity from that in developed countries. The main reason for higher labor productivity in the USA and other developed countries is much higher fixed capital per employee, the capital-labor ratio and the power supply-to-labor ratio than in Russia [1]. Other factors are of great importance, too. In particular, research and development aimed at improving production efficiency [2], high level of organization and management of production, development and application of scientifically-based labor standards at enterprises [3], high skills of workers, efficient use of working time.

The experience of Russian enterprises shows that the last factor, efficient use of working time, is one of the low-cost but effective tools to increase staff labor productivity. It is known that the more hours of working time there is per worker, and the more efficiently it is used, the higher is labor productivity. However, at Russian enterprises there is a problem of rational use of working time because of shortcomings in the organization of labor and a low level of labor discipline that cause loss of time. This leads to lower level of labor productivity of individual workers and adversely affects the performance of the whole enterprise. The international comparison of the level of labor productivity per employee and actual hours worked showed that in spite of Russia's serious lagging in the first indicator, it overtook other countries in the number of hours worked. For example, in 2016, the number of actual hours worked per average worker in Russia was 1.46 times higher than in Germany, 1.4 times higher than in Norway and Denmark, 1.3 times higher than in France and Luxembourg and 1.1 times higher than in the USA.

So, the advisability of periodical evaluating of the use of working time and analyzing of the causes of its loss is one of the necessary factors of working time rationalizing and sustainable increase of labor productivity at Russian enterprises.

\section{Problem Statement}

One of the tools having a direct impact on labor productivity is the rationalization of working time which leads to a reduction in losses and an increase in useful working time.

In many scientific works it is noted that the reduction of working time loss directly affects the labor efficiency of workers [4-6]. Time management becomes the subject of a number of scientific studies [7]. Many economists think that there is a close relationship between the level of working time use and labor productivity [8]. Productivity of labor increases proportionally to the level of labor discipline. This leads to increased efficiency of working time use at the enterprise. Thus, factors of labor productivity increase at the workplace include, first of all, a set of measures to eliminate the loss of working time and more rational use of it [9]. 
The results of the study conducted by a group of foreign scientists indicate that an increase in the number of hours worked leads to an increase of fatigue, which in turn affects the efficiency of labor. It tends to decrease [2]. Recently the international community has been paying considerable attention to flexible working time, i.e. the form of organization of working time, in which within certain limits, the employee can independently determine the hours of work per shift. Continuous use of flexible working hours contributes to increased labor productivity of employees [5] more than the use of fixed working time [10].

\section{Research Questions}

Russian enterprises have accumulated certain experience in studying working time costs. A variety of methods is used to assess the efficiency of working time: working time photography, time observation method, moment observation method, photo synchronization, etc. However, high labor intensity of the work of specialists in labor valuation, a significant amount of information processed, the low level of automation of labor valuation work does not allow making full analysis of the causes of losses and unproductive labor time, to develop measures aimed at improving its use. It affects the productivity of labor of employees of organizations. Thus, the advisability of periodical analyzing of losses and unproductive use of working time and evaluating the effectiveness of its use is one of the factors of improving the state of labor valuation and raising the productivity of labor of workers at Russian enterprises.

\section{Purpose of the Study}

The purpose of the study, the results of which are reflected in this article, is the analysis of the problems associated with inefficient use of working time at Russian enterprises and the search for ways to solve them as well as the development of an algorithm for calculating and evaluating the efficiency of working time.

To achieve this goal during the study the following tasks were solved:

- there was justified the order of assessing the efficiency of the use of working time and reserves for the increase of labor productivity and the corresponding flowchart was presented;

- there were given the calculations of indicators of working time, a possible increase in labor productivity due to the elimination of losses during a shift, and the reserves of labor productivity increase due to better use of working time on the example of one of the Samara enterprises;

- the structure of the work of the preparatory-final time and time of maintenance of the workplace, the composition of losses and inefficiently used working time were analyzed;

- the main directions for improving the use of working time at enterprises, taking into account the reasons of its losses and inefficient use were worked out.

\section{Research Methods}

Evaluation of the efficiency of working time involves the analysis of indicators of working time and the reasons of its losses, the determination of possible labor productivity growth by eliminating these losses, the definition of reserves of labor productivity increase by better use of working time (Fig. 1).

\begin{tabular}{|l|l|}
\hline \multicolumn{2}{|c|}{ Stages of evaluating the efficiency of working time } \\
\hline $\begin{array}{l}\text { 1. Analysis of working time indicators } \\
\text { 2. Analysis of the reasons of losses and inefficient use of working time }\end{array}$ \\
$\begin{array}{l}\text { 3. Calculation of the possible increase of labour } \\
\text { productivity due to the reduction of shift time losses } \\
\text { with the use of working time photos ( } \triangle \mathrm{LP})\end{array}$ \\
\begin{tabular}{|l|l|} 
T. Assessment of reserves of labour productivity increase on the account of improving the use \\
of working time LP (STF)
\end{tabular} \\
\hline $\begin{array}{l}\text { Top (n, f) - normative (factual) } \\
\text { amount of operative time, min. }\end{array}$ \\
$\begin{array}{l}\text { STF - Shift time fund of one worker per year, days (hours); STLP-Shift time loss of one } \\
\text { worker per year, days (hours), planned; STLF - Shift time loss of one worker per year, days } \\
\text { (hours), fact }\end{array}$ \\
\hline
\end{tabular}

Figure 1. Algorithm for Evaluating the Effectiveness of the Use of Working Time and Determining the Reserves of Labor Productivity Increase (Source: compiled by the authors) 
The most frequently used methods of finding out the loss of time at enterprises are photographs and selfphotographs of working time. To study the use of working time of a brigade of workers, a group photograph of working time is used, the peculiarity of which is simultaneous observation of several workers. However, the balances of a working day are compiled for each worker of a brigade separately and for a whole brigade. Evaluation of the efficiency of working time use is completed by the development of measures to eliminate losses and non-productive use of working time.

\section{Findings}

The object of the research was the brigade of 5 workers of the emergency-recovery section of one of Samara enterprises replacing stop-regulating valves with a diameter of $500 \mathrm{~mm}$. Group photograph of working time was being carried out for 3 days. The fixation of all the actions of the working brigade on a previously prepared observation sheet during the entire observation period was carried out by the equal interval (10 minutes) method. According to the results of the observations, the average indicators of the same-time working time costs were calculated for each employee of the brigade per working day (Table 1) and the total actual balance was compiled (Table 2).

Table 1. Factual Working Time Balance for Each Worker

\begin{tabular}{|c|c|c|c|c|c|c|c|c|c|c|}
\hline \multirow{2}{*}{$\begin{array}{l}\text { Working } \\
\text { time costs }\end{array}$} & \multicolumn{2}{|c|}{ The first worker } & \multicolumn{2}{|c|}{$\begin{array}{l}\text { The second } \\
\text { worker }\end{array}$} & \multicolumn{2}{|c|}{ The third worker } & \multicolumn{2}{|c|}{ The fourth worker } & \multicolumn{2}{|c|}{ The fifth worker } \\
\hline & minutes & $\%$ & minutes & $\%$ & minutes & $\%$ & minutes & $\%$ & minutes & $\%$ \\
\hline OP & 197 & 34 & 210 & 37 & 230 & 40 & 207 & 36,1 & 210 & 37 \\
\hline PF & 240 & 42 & 243 & 42 & 240 & 42 & 226 & 39,4 & 243 & 42 \\
\hline $\mathrm{M}$ & 52 & 9,0 & 53 & 9,2 & 32 & 5,5 & 53 & 9,2 & 53 & 9,2 \\
\hline RPN & 17 & 3,0 & 17 & 3,0 & 17 & 3,0 & 17 & 3,0 & 17 & 3,0 \\
\hline NDEB & 47 & 8,3 & 37 & 6,5 & 37 & 6,5 & 37 & 6,5 & 37 & 6,5 \\
\hline LDVB & 20 & 3,7 & 13 & 2,3 & 17 & 3,0 & 33 & 5,8 & 13 & 2,3 \\
\hline Total & 573 & 100 & 573 & 100 & 573 & 100 & 573 & 100 & 573 & 100 \\
\hline
\end{tabular}

Source: compiled by the authors.

Table 2. The Time Balance of the Average Worker of the Brigade

\begin{tabular}{|c|c|c|c|c|c|}
\hline \multirow[t]{2}{*}{ Working time costs } & \multirow[t]{2}{*}{ Index } & \multicolumn{2}{|c|}{ Factual } & \multicolumn{2}{|c|}{ Normative } \\
\hline & & minutes & $\%$ & minutes & $\%$ \\
\hline Preparatory-final time & $\mathrm{PF}$ & 239 & 41,7 & 178 & 31 \\
\hline Operative time (job related work) & OP & 209 & 36,5 & 361 & 63 \\
\hline Working place maintenance time & $\mathrm{M}$ & 48 & 8,4 & 14 & $\begin{array}{c}2, \\
4\end{array}$ \\
\hline Time for rest and personal needs & RPN & 17 & 3,0 & 11 & $\begin{array}{l}2, \\
0\end{array}$ \\
\hline Breaks not dependent on employees & NDEB & 41 & 7,1 & 9 & $\begin{array}{l}1, \\
6\end{array}$ \\
\hline Breaks caused by labor discipline violations & LDVB & 19 & 3,3 & - & - \\
\hline Total & & 573 & 100 & 573 & $\begin{array}{c}10 \\
0\end{array}$ \\
\hline
\end{tabular}

Source: compiled by the authors.

According to the actual working time balance, the use of working time of the brigade was calculated: working time use ratio $(89.5 \%)$, the ratios for organizational and technical reasons $(7.1 \%)$ and due to violations of labor discipline (3.4). The high proportion of preparatory and final time $(41.7 \%)$ is due to the traveling nature of the work, the specifics of its performance. Significant losses of time (10.4\%) are caused by organizational and technical reasons (waiting and delays in work).

According to the results of expert estimation taking into account that the work demands moving to different places, standards were established for preparatory and final work (178 minutes), workplace maintenance (4\%) and for leisure and personal needs $(3 \%)$. Due to the elimination of loss of working time during the shift, labor productivity increases by $72.7 \%$. Determination of the value of reserves for the increase of labor productivity due to effective use of time was carried out by comparing the available fund of working time at the enterprise with the factual working time (Table 3 ).

Table 3. The calculation of the reserves for labor productivity (LP) increase due to better use of working time

\begin{tabular}{|c|c|c|c|c|c|c|c|}
\hline \multirow{3}{*}{ Indicators } & \multirow{2}{*}{\multicolumn{2}{|c|}{ Nominal fund }} & \multicolumn{4}{|c|}{ Time losses } & \multirow{3}{*}{$\begin{array}{c}\text { Labor } \\
\text { productivity } \\
\text { increase } \\
\text { reserves }\end{array}$} \\
\hline & & & \multicolumn{2}{|c|}{$\begin{array}{l}\text { According to } \\
\text { the plan }\end{array}$} & \multicolumn{2}{|c|}{ Actually } & \\
\hline & Abs & $\%$ & Abs & $\%$ & Abs & $\%$ & \\
\hline
\end{tabular}




\begin{tabular}{|c|c|c|c|c|c|c|c|}
\hline $\begin{array}{c}\text { Full-day time fund of } \\
\text { one worker per year, } \\
\text { days }\end{array}$ & 247 & 100 & 32 & 12,9 & 43,9 & 17,8 & $5,86 \%$ \\
\hline $\begin{array}{c}\text { Shift time fund of one } \\
\text { worker, hours }\end{array}$ & 8 & 100 & 0,07 & 0,9 & 0,12 & 1,5 & $0,63 \%$ \\
\hline $\begin{array}{c}\text { General fund of } \\
\text { working time per } \\
\text { worker per year, } \\
\text { hours }\end{array}$ & 1976 & 100 & 271,1 & 13,7 & $\begin{array}{c}375, \\
6\end{array}$ & 19,0 & $6,5 \%$ \\
\hline
\end{tabular}

Source: compiled by the authors.

Thus, the results of the study show that one of the promising reserves for the increase of labor productivity at Russian enterprises that do not require additional funding and allow increasing of the efficiency of personnel during the shortest period of time, is to increase the efficiency of working time use.

\section{Conclusion}

Specific measures for improving the use of working time should take into account the specifics of the activities of the staff of the organization, the reasons of losses and waste of time (Figure 2). For example, reducing absenteeism for reasons of illness involves a set of measures related to annual medical examination of employees to identify occupational diseases; improving sanitary and psycho-physiological working conditions; improving ergonomics of the workplace, systematic instructions on safety, etc. Recommendations for the elimination of wasted time must be developed taking into account their reasons: low level of labor discipline at the enterprise and shortcomings in production supply and management as well as work organization.

The Main Directions of Improving the Efficiency of Working Time Use

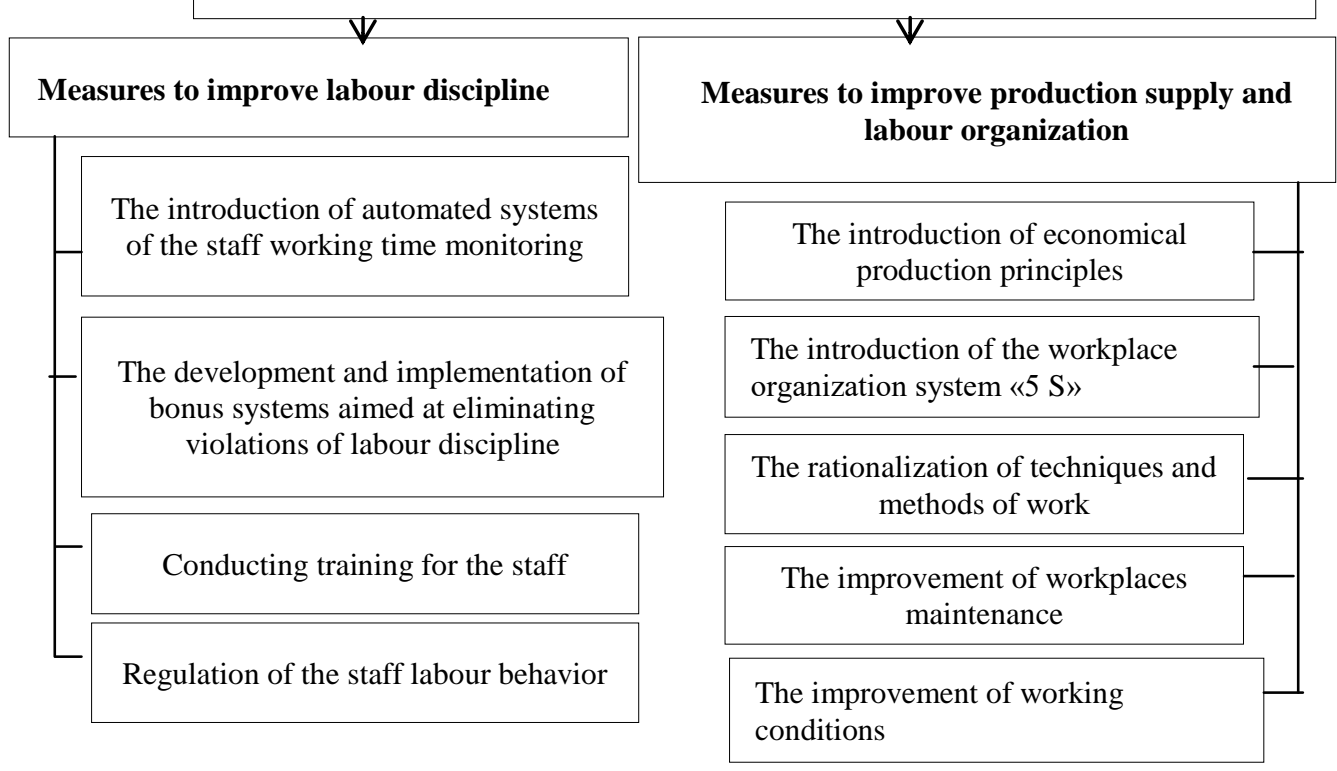

Figure 2. Directions of Improving the Efficiency of Working Time Use (Source: compiled by the authors)

The proposed measures to eliminate working time losses will help enterprises to use working time fund in the most efficient way increasing staff labor productivity and general performance of an enterprise.

So, it is necessary to develop an integrated system of working time management, which is an important direction of increasing labor productivity at enterprises in modern conditions.

\section{References}

1. V.A. Vaisburd, M.V. Simonova, I.V. Bogatyreva, E.G. Vanina, E.P. Zheleznikova, Productivity of labor and salaries in Russia: Problems and solutions. International Journal of Economics and Financial Issues, 6(S5), 157-165 (2016). 
2. F. Venturini, The modern drivers of productivity. Research Policy, 44(2), 357-369. DOI: 10.1016/j.respol.2014.10.011 (2015).

3. V.A. Schekoldin, I.V. Bogatyreva, L.A. Ilyukhina, V.M.Kornev, Development of IT-technologies in labor standardization and quality assessment of standards: Challenges and ways of solution in Russia. Helix, 8(5), 36153628. DOI: 10.29042/2018-3615-3628 (2018).

4. M. Collewet, J. Sauermann, Working hours and productivity. Labor Economics, 47, 96-106 (2017).

5. C. Durana, A. Cetindereb, Y. Emre Aksuc, Productivity improvement by work and time study technique for Earth energy-glass manufacturing company. Procedia Economics and Finance, 26, 109-113 (2015).

6. G. Espinosa-Garza, I. Loera-Hernández, N. Antonyan, Increase of productivity through the study of work activities in the construction sector. Procedia Manufacturing, 13, 1003-1010. DOI: 10.1016/j.promfg.2017.09.100 (2017).

7. P.B. Skrynchenko, Efficient use of working tme. Interaktivnaya Nauka, 10, 154-156 (2016). [in Rus.].

8. S. Park, N. Yaduma, A.J. Lockwood, A.M. Williams, Demand fluctuations, labor flexibility and productivity. Annals of Tourism Research, 59, 93-112. DOI: 10.1016/j.annals.2016.04.006 (2016).

9. S.V. Rachek, A.V. Miroshnik, Productivity as key performance indicator of work. Modern Problems of Science and Education, 6. URL: https://www.science-education.ru/ru/article/view?id=11461. Accessed: 23/01/2019 (2013). [in Rus.].

10. M. Beckmann, T.Cornelissen, M. Kräkel, Self-managed working time and employee effort: theory and evidence. Journal of Economic Behavior \& Organization, 133, 285-302 (2017). 